\title{
German plans may increase competition ...
}

Munich. The German cabinet last week approved plans drawn up by the research ministry to improve the efficiency of federally funded research institutes. Jürgen Rüttgers, the research minister, said that the proposed changes - most of which have to be approved by the Länder (state) governments - would "allow us to fund the best [research] through competition".

One change is that scientists in so-called 'blue list' institutes will compete with university scientists for part of the money that they at present receive automatically.

Scientists have welcomed the plan, but still express concern in private. Initially the research ministry had been thinking of transferring up to 20 per cent of the blue list's institutional financing to the Deutsche Forschungsgemeinschaft (DFG), Germany's basic research funding agency, to be redistributed as project money through open competition. But, aware that the plan needs to be introduced cautiously if it is to win public acceptance, this transfer will be limited to 5 per cent under the plan approved by the cabinet.
Scientists are now hoping that the ministry will also be prepared to compromise on its desire that all blue-list research institutes - including those in the east, which have hardly begun to find their feet - will be included in its plan.

Blue-list institutes are a mixed bag of research and service institutes jointly funded by federal and Länder governments. After reunification, many institutes of the East German Academy of Sciences that were judged by the German science council, the Wissenschaftsrat, to be of good quality, were placed in this category (see Nature 363, 482; 1993). This nearly doubled their total number, now standing at 83 . But the increased funding involved attracted the attention of critics, who argued that such institutes had never been subject to systematic quality control (see Nature 377, 466; 1995).

According to Ingo Hertel, president of the WBL, the new organization that defends the general interests of the blue-list institutes, the proposal to put part of their budgets into a common pot of project money will increase the amount of quality

\section{... and hammer geological research}

Munich. German scientists, who until recently have escaped the significant budget restrictions experienced by their European neighbours, will soon be sharing the same fate. Jürgen Rüttgers, Germany's research minister, announced last week that his ministry is not to be exempt from cuts averaging 2.5 per cent being applied to all government spending in the federal budget for 1997.

The latest cuts are intended to help Germany meet the financial criteria for entry into the European monetary union. When added to budget cuts announced earlier this year (see Nature 381, 9; 1996), the result will be a reduction of 4.5 per cent next year on the originally-approved 1996 budget for science and research.

Geological sciences will suffer most in financial terms, with a 40 per cent reduction in funding, although much of this will be the result of the completion of Germany's large continental drilling programme in northern Bavaria, known as KTB (Kontinentaltiefbohrprogram), at the end of this year.

Rolf Emmermann, the Going down: the world's scientific director of the largest on-shore drill rig Geoforschungszentrum

in will soon finish its work
Potsdam, Germany's largest geological sciences institute, says he hopes the research ministry will eventually agree to support a replacement large-scale Earth sciences programme. But he accepts that this is no longer guaranteed.

"We will have to explain our relevance to society," says Emmermann. He predicts that there will be a move away from basic research to "some kinds of early-warning systems for earthquakes, floods, or volcanoes". The whole of Earth sciences is entering a crisis, he says, as nearly all publicly funded research projects will run out by 1998.

Ocean and polar research will also to be hard hit by the latest round of cuts, each being cut by 11 per cent in project money, and a smaller amount in institutional support.

In contrast, there is good news both for the Max Planck Society and the Deutsche Forschungsgemeinschaft (DFG), which funds university research. Government promises to maintain the annual 5 per cent increase they have enjoyed for the past six years will be honoured in the 1997 budget. $\quad$ Q. S. \& A. A. control and raise the level of research. But he says that its success will depend on how the idea is put into practice. It should not be imposed on all institutes, he says.

Christof Schneider, a spokesman for the DFG, agrees. Blue-list institutes may object if they fail to win back the research funds on which they used to rely, and see the money going to universities. Some of the new institutes in the east have not yet even appointed directors, he says, and are too young to have to face such a strain.

The DFG has other concerns about the plan. Despite an annual increase in funding of 5 per cent over the past few years, the agency is struggling with an increase in the number of research applications, mostly from universities, which has grown at the much faster rate of 10 per cent per year. The additional burden of handling even more applications from blue-list scientists could prove too great to maintain the efficiency that the research ministry praised in its paper.

Second, the DFG is concerned about what Schneider calls the "ethical question" of whether giving it responsibility for part of the blue-list budget could force the agency into an unwelcome political role that it has successfully avoided in the past

Negotiations are taking place to resolve these issues. But it is already clear that the hopes of the research ministry that the new system will be in place by next January are unrealistic. Any changes to the budgetary system of blue-list institutes requires the formal approval of the Länder governments, and negotiations are likely to be difficult.

The research ministry's strategy paper also suggests that parts of the budgets of Germany's 16 national research centres, often criticized as inefficient (see Nature 372, 4; 1994), should eventually be handled by the DFG in the same way.

More immediately, it suggests that the newly created senate of the Helmholtz Society, which represents the centres nationally, should control part of the general institutional budgets, which cover running costs and salaries, directing the money to national research centre departments working in priority areas which it will be responsible for defining. The senate comprises experts from the political, scientific and industrial areas.

Joachim Treusch, who is director of both the Helmholtz Society and the KFA research centre in Jülich, is enthusiastic about this suggestion, which he believes will help the national research centres to contribute effectively to Germany's strategic needs. But he does not support a future role for the DFG in handling project money. That would make the financing of the centres too complicated, he says, if they already have to apply for money from the senate and from industry.

Alison Abbott \& Quirin Schiermeier 